\title{
Using the Technology Acceptance Model to Understand Attitudes about a Virtual Learning Environment for EFL Writing
}

\section{Charles Copeland ${ }^{1}$, John Franzese ${ }^{2}$}

${ }^{1}$ First Author, Foreign Language Teaching Assistant Professor, College of Liberal Arts, Dankook University, dankookclass@gmail.com

${ }^{2}$ Corresponding Author, Assistant Professor, College of Liberal Arts, Dankook University, john.franzese@gmail.com

\section{Abstract}

This quantitative case study used Venkatesh and Davis' (2000) technology acceptance model (TAM) to understand EFL student attitudes towards using a virtual learning environment (VLE). The study surveyed 97 undergraduate students enrolled in a required English writing course. The study employed factor reduction to group the variables into the TAM. A standard multiple regression was then performed to determine the effect the variables had on the model. It was found that the perceived ease of use (EoU), output quality (OQ), and results demonstrability (RD) had a positive statistical effect on the perceived usefulness (PU). The subjective norm (SN), EoU, and PU also had a positive statistical effect on the students' intention to use (IU) the VLE for writing. The final standardized regression found a positive statistical effect from IU towards the students' usage behavior (UB). The overall results showed that the more positive a student's EoU, OQ, RD, SN, PU, and IU, the more likely a student will use and accept the VLE for writing. This usage should also help students improve their language level as well as build $4^{\text {th }}$ industrial revolution skills. Teachers should consider the use of VLEs to teach or supplement EFL writing in the future.

Key Words: technology acceptance model (TAM), virtual learning environments (VLE), EFL writing, $4^{\text {th }}$ industrial revolution, student attitudes

These authors contributed equally to this work.

1. Introduction

2. Literature Review

3. Methods

4. Results

5. Discussion

6. Conclusion and Suggestions 


\section{Introduction}

As digital technology has continued to advance, its presence in the education sector has become ever more apparent (Raja \& Nagasubramani, 2018). This new technology has provided teachers with an additional resource, another tool at their disposal, to improve the learning experience for their students in the physical classroom. Digital technology has proven itself to be a valuable resource that is quickly becoming a mainstay of the educational system (Boonmoh et al., 2021; Ni, 2013). However, questions remain about how this technology can be tailored and adapted to specific subjects or whether this technology can fully replace the physical classroom.

Currently, a global pandemic has wrought havoc across the world. COVID-19 is a virus that has forced many countries to rethink how education should be approached. As a safety precaution and to limit the spread of COVID-19, many schools have opted to hold classes online (Cai et al., 2020; Ock, 2020). According to UNESCO, as many as 143 nations have implemented nationwide closures of schools (https://en.unesco.org/covid19/educationresponse). In effect, this pandemic has shifted the preferred medium of teaching in a physical classroom to a digital online classroom, drastically changing the landscape of how teachers and students interact.

While schools around the globe have to contend with the shift from a physical to a digital classroom, this transition affects each subject differently. Within English as a Foreign Language (EFL) education, academic writing is a class commonly taught at the university level. EFL academic writing often employs digital resources to supplement teaching in the physical classroom (Townsend et al., 2013). Therefore, this subject may lend itself more readily to transitioning to an utterly online-based system of learning. Further exploration of the shift from a physical offline classroom to a digital online classroom may help provide insight into how beneficial technology is and whether it is sustainable as the sole means of educating EFL students in writing. This current study seeks to understand how technology, specifically the perception of online platforms or Virtual Learning Environments (VLE), helps students in EFL writing.

\section{Literature Review}

\subsection{Technology Use and Acceptance in the Classroom}

The incorporation of digital technology into the classroom has vastly altered how teachers teach and how students learn. By embracing the use of digital technology, it's possible to surpass the physical confines of the in-person classroom; therefore, increasing the medium through which teachers can connect with students and students among each other (Nelson, 2013; O'Connor, 2020). The use of mobile technology, which provides access to VLEs through various educational applications, has continued to show an increase in use and perceived usefulness by both teachers and students (Anatolyevna et al., 2018; Davison \& Lazaros, 2015). Surani and Hamidah (2019) state that the utilization of online learning allows students to easily connect and provide students with an opportunity to share and utilize subject matter from a variety of sources that would help increase learning efficiency. Their study also finds that students are willing to continue using online learning methods citing convenience as a factor.

As the world enters the 4th Industrial Revolution, using technology in the classroom to teach real-life skills becomes a facet of all subjects, including EFL (Alakrash \& Razak, 2020; Hashim \& Yunus, 2019). Jones et al. (2019) found that Korean EFL students generally had positive feelings towards technology in the $4^{\text {th }}$ Industrial Revolution but were not as positive towards their use in learning English. Teacher readiness was one reason that was given. Wen and Kim Hua (2020) found that a teacher's self-perceived ICT competence, accessibility of infrastructure and online resources, and suitability of the work environment were all positive predictors of 
teacher behavioral intention related to using $4^{\text {th }}$ Industrial related skills in the classroom. However, Kit and Ganapathy (2019) found that there could be difficulties for teachers making this adjustment, including lack of awareness, lack of time, lack of ICT skills, lack of training, and lack of infrastructure.

With the outbreak of Coronavirus in early 2020, schools had to turn to the use of 4th Industrial Revolution skills to teach all subjects (Wen \& Kim Hua, 2020). According to UNESCO, COVID-19 has been the cause of schools worldwide temporarily shutting down, affecting approximately 1.2 billion students in 186 countries since the beginning of 2020. As a result, schools have been compelled to utilize online platforms or transition to blended or hybrid learning practices. Graham (2006) defines the method of blended learning as follows: "Blended learning systems combine face-to-face instruction with computermediated instruction" (p. 5). Essentially, education has been forced to accept technology to connect teachers and students to maintain effective class instruction. In response to the COVID-19 pandemic, online-based virtual learning environments have been used by the vast majority of universities worldwide (O'Connor, 2020) as a replacement for classes previously taught in person. This pandemic has become the impetus to push technology forward in an unprecedented manner that can highlight its advantages and flaws. Although technology's fundamental role in education began as a tool to aid in learning, this unforeseen shift has propelled technology to the forefront, making it the primary vehicle for how teachers and students connect across the globe.

\subsection{Learning Writing through Online Technology}

Writing is a production-based skill that requires its creators to record their thoughts in the written word. Traditionally this skill was used with a scribe on a functional surface, but as technology progressed, new tools and mediums allowed creators to record their writing in more innovative ways. Printing presses and later typewriters allowed writing to be created more easily and disseminated to a broader audience. It is no surprise that the computer and the digital landscape in which it thrives have given rise to a new form of writing and further expanded the number of users and audiences that can be reached.

The subject of writing has been closely tied with the use of online resources to promote learning. Shepherd (2018) points out that digital writing is practiced regularly in many facets of modern life and should be acknowledged as an essential element of current writing classes. The concept of utilizing online learning platforms to foster and promote writing skills is a trend that has existed for some time (Townsend et al., 2013). The benefits provided by online-based writing tools have often been implemented in conjunction with in-person classes. Online resources allow for the potential for faster feedback and more in-depth explanations that enable students to recognize their errors and make corrections promptly. Ni (2013) also echoes that the quality and quantity of interaction between students and teachers may be increased through using online platforms for teaching writing.

While it is clear that technology not only has a place in the writing classroom, it will likely remain an integral part of teaching methodology indefinitely. Much research focuses on how this technology is used in conjunction with face-to-face learning, such as flipped classrooms or blended learning. Yet, as has been illustrated by the Coronavirus pandemic, there is likely a chance that using online platforms to conduct classes may become the sole teaching method. As Griffin and Minter (2013) point out, much research has been undertaken on developing effective in-person teaching techniques and methodologies. However, that same attention must also be given to learners working in an online environment, showing an existing gap in addressing teaching in an online environment.

\subsection{Technology Acceptance Model}

Technology's use in the classroom remains an ever- 
growing and dynamic element of teaching and learning. As a result, how the use of this technology is perceived and its acceptance is also in constant flux. The Technological Acceptance Model (TAM) introduced by Davis (1986) and further developed as the TAM2 (Venkatesh \& Davis, 2000) can be used to help understand how its users accept this technology.

The theory behind TAM centers on the individual's intention to use a given system determined by two primary beliefs; perceived usefulness and perceived ease of use (Davis, 1989; Davis et al., 1989). The first belief is the user's perceived usefulness, which reflects how a system can be used to enhance their job, or in education, to successfully learn and complete the task at hand. The second belief, perceived ease of use, refers to how a user believes they are capable of using a particular system. Based on users' perceived usefulness and ease of use in a system, their intent to use or continue using this system will be affected. The TAM2 further elaborates on Davis's initial TAM model through the addition of factoring in social influence processes (Venkatesh \& Davis, 2000).

For the survey, the TAM was broken into three stages. The first stage uses the subjective norm $(\mathrm{SN})$, output quality (OQ), results demonstrability (RD), and perceived ease of use (EoU) to predict the students' perceived usefulness (PU) of the online writing system. The second stage of the model explores how well SN, PU, and EoU can be used as predictors for the student's intention to use (IU) the technology. The final stage delves into the relationship between IU and the online writing system's usage behavior (UB) (See [Figure 1]).

Subjective norm refers to the social influences exerted on the users of the online system for writing. Amjad et al. (2020) defined SN as "the social influence or the influence of colleagues, friends, and teachers on learners' acceptance" (p. 155) of a technology.

Output quality refers to the job relevance of the technology being studied (Venkatesh \& Davis, 2000). In the case of an online writing system, the quality of the feedback would be necessary for student writing improvement.

Results demonstrability refers to how well a user can explain how the technological system aids their development. As Venkatesh and Davis (2000) explained, "Even effective systems can fail to garner user acceptance if people have difficulty attributing gains in their job performance specifically to their use of the system" (p. 192).

In accordance with the TAM model, this study will seek answers to the following questions:

1. How to $\mathrm{SN}, \mathrm{OQ}, \mathrm{RD}$, and EoU relate to the learners' perceived usefulness of VLEs for EFL writing?

2. How do SN, PU, and EoU relate to the learners' intention to use VLEs for EFL writing?

3. How does the learners' intention to use relate to usage behavior with VLEs for EFL writing?



[Figure 1] Structural Model for Student Attitudes towards Online Writing Systems Using the TAM 


\section{Methods}

\subsection{Participants}

A total of 97 students enrolled in a required English writing course at a mid-sized Korean university were given a survey about their perception of using an online writing system based on the Technology Acceptance Model (TAM). The survey was performed across two terms which met in the Spring term 2020 and 2021. The students were predominately in their first year at university, with 76 students reporting they were in the first year. Six students said that they were second-year students. A total of five students were in their third year, and eight were in their fourth year. Two students did not respond. The students were enrolled in a range of majors. The largest number of students were enrolled in engineering: 23 students. Eighteen business majors answered the survey, along with eight students who studied the humanities. There were seven students each enrolled in architecture, computer sciences, and education. Six students studied the social sciences. There were five arts and communication majors, and one student stated they studied law. Finally, ten students did not report their major.

\subsection{Procedures}

The class was a three-credit-hour class that was taught over two 90-minute class periods. The classes met a total of 30 times over the 15 -week semester as laid down by the university. The online writing classes consisted of videos based on the course textbook, followed by homework assignments. The homework was broken into assignments aimed at gauging a student's participation with the video and writing tasks submitted to and then graded using an online system. Writing tasks were assessed using a rubric and a checklist by both teachers. The examinations for the class were also held online due to the safety issues surrounding COVID-19.

\subsection{Data Collection}

The students were given a link to the survey, which was posted on the class website at the end of the semester. There was a notice that participation was voluntary and that no identifying information would be collected Students were asked to respond to 20 items broken into six factors of usage behavior based on Venkatesh and Davis' (2000) TAM structure (see <Table 1>). Each question is on a four-point Likert-type scale with a four equaling strongly agree, and one equated to disagree strongly. The survey was administered through Google Forms.

\subsection{Data Analysis}

The results were imported to IBM SPSS Statistics (Version 26) for statistical analysis. The descriptive statistics were first determined. The following test was to check if the data could be broken into planned factors by checking internal reliability and the feasibility of a factor reduction. The factors were then analyzed using a linear reduction to determine the way the variables completed the model. If all of the questions did not have a response, that response was removed listwise for analysis.

\section{Results}

This section reports the results. The first section reports the descriptive statistics for the items asked on the survey. The assumptions for the test are then defined. Finally, the results of a standard multiple regression will be explored for the three stages of the model. The first stage explains what factors out of $\mathrm{EoU}, \mathrm{SN}, \mathrm{OQ}$, and $\mathrm{RD}$ affect PU. Next, a multiple regression was performed to determine how EoU, SN, and PU affect IU. Finally, the results of statistical regression to determine the effects of IU on UB. 


\subsection{Descriptive Statistics}

The items on the survey were broken into seven factors. The first factor of usage behavior (UB) contained a single item with a mean of 3.58. The second factor, intention to use (IU), had items ranging from 3.30 to 3.13. All of these scores were between strongly agree and agree. The third factor, perceived usefulness (PU), had four items with an average response ranging from 3.46 to 3.08. The next factor was perceived ease of use (EoU) which had four items with a range of average scores between 3.46 and 3.04. Subjective norm (SN) was the fifth factor with two questions that had two of the three lowest average responses at 3.02 and 2.77. SN also had the largest standard deviation, implying a more extensive range of differences in the responses. Output quality (OQ) was the sixth factor, which had three items, with a range of responses from 3.22 to 3.01. Finally, result demonstrability (RD) also had three items and had average responses between 3.23 and 3.12 (see <Table 1>).

All but one of the response averages was between strongly agree and agree, except for Item 14: People who

〈Table 1〉 Means of the Items, Standard Deviation, and Common Factor Load

\begin{tabular}{|c|c|c|c|c|}
\hline Factors and Items & $\begin{array}{l}\text { Cronbach's } \\
\text { Alpha }\end{array}$ & Mean & S.D. & $\begin{array}{c}\text { Factor } \\
\text { Load }\end{array}$ \\
\hline $\begin{array}{l}\text { Factor 1: Usage Behavior } \\
\text { 1. Currently, I am required to use an online platform to submit my writing homework. }\end{array}$ & & 3.58 & .599 & .799 \\
\hline $\begin{array}{l}\text { Factor 2: Intention to Use (IU) } \\
\text { 2. Based on my experience, I am satisfied with using an online platform to learn writing. } \\
\text { 3. My experience with using an online platform to learn writing has met my expectations. } \\
\text { 4. If I had the opportunity to use an online platform to learn writing in the future, I would use it. }\end{array}$ & .722 & $\begin{array}{l}3.30 \\
3.17 \\
3.13\end{array}$ & $\begin{array}{l}.726 \\
.640 \\
.767\end{array}$ & $\begin{array}{l}.805 \\
.860 \\
.793\end{array}$ \\
\hline $\begin{array}{l}\text { Factor 3: Perceived Usefulness (PU) } \\
\text { 5. I feel that using an online platform to submit my writing homework has helped improve } \\
\text { my writing ability. } \\
\text { 6. Using an online platform to submit writing homework increases my productivity. } \\
\text { 7. Using an online platform to submit writing homework enhances my learning effectiveness. } \\
\text { 8. I find an online platform to submit writing homework to be useful. }\end{array}$ & .859 & $\begin{array}{l}3.24 \\
3.08 \\
3.46 \\
\end{array}$ & $\begin{array}{r}.769 \\
.796 \\
.673 \\
\end{array}$ & $\begin{array}{l}.684 \\
.743 \\
.645 \\
\end{array}$ \\
\hline $\begin{array}{l}\text { Factor 4: Perceived Ease of Use (EoU) } \\
\text { 9. My interaction with an online platform to submit writing homework is clear and understandable. } \\
\text { 10. Interacting with an online platform to submit writing homework does not require a lot } \\
\text { of mental effort. } \\
\text { 11. I find using an online platform to submit writing homework to be easy to use. } \\
\text { 12. I find it convenient to access an online platform to complete my homework. }\end{array}$ & .781 & $\begin{array}{l}3.39 \\
3.04 \\
3.39 \\
3.46\end{array}$ & $\begin{array}{l}.714 \\
.820 \\
.730 \\
.690\end{array}$ & $\begin{array}{l}.528 \\
.791 \\
.881 \\
.850\end{array}$ \\
\hline $\begin{array}{l}\text { Factor 5: Subjective Norm (SN) } \\
\text { 13. People who influence my behavior (friends, classmates, parents, etc.) think that online } \\
\text { platforms are beneficial for learning. } \\
\text { 14. People who are important to me think that I should use an online platform to improve } \\
\text { my learning experience. }\end{array}$ & 673 & 3.02 & .834 & .729 \\
\hline $\begin{array}{l}\text { Factor 6: Output Quality (OQ) } \\
\text { 15. The quality of the feedback I get from an online platform to submit writing homework is high. } \\
\text { 16. The quality of feedback I get from an online platform to submit writing homework is higher } \\
\text { than I would receive offline. } \\
\text { 17. My experience with using an online platform to learn writing has met my expectations. }\end{array}$ & .788 & $\begin{array}{l}3.22 \\
3.01 \\
3.17\end{array}$ & $\begin{array}{l}.804 \\
.828 \\
.640\end{array}$ & $\begin{array}{l}.846 \\
.766 \\
.860\end{array}$ \\
\hline $\begin{array}{l}\text { Factor 7: Result Demonstrability (RD) } \\
\text { 18. I have no difficulty telling others about the results of using an online system to submit } \\
\text { writing homework. }\end{array}$ & .729 & 3.23 & .601 & .793 \\
\hline $\begin{array}{l}\text { 19. I believe I could communicate to others the consequences of using an online system to } \\
\text { submit writing homework. }\end{array}$ & & 3.12 & .700 & .820 \\
\hline 20. The results of using an online system to submit writing homework are apparent to me. & & 3.23 & .562 & .626 \\
\hline
\end{tabular}


are important to me think that I should use an online platform to improve my learning experience was the lowest item and the only one between agreeing and disagreeing at 2.77. Item 1: Currently, I am required to use an online platform to submit my writing homework had the highest score of any item on the survey at 3.58 . This result is understandable because all classes were required to submit writing homework through an online system. The standard deviations ranged from .599 to .887 .

\subsection{Assumptions}

To determine if the sample size was appropriate for factorial analysis, Beavers et al. (2013) stated two statistical tests should be applied: the Kaiser-Meyer-Olkin value (KMO) and Bartlett's Test of Sphericity (BTS). The KMO was found to be .844 , which is considered meritorious according to Dziuban and Shirkey (1974). And the BTS was found to be significant at an approximate $\chi^{2}(171)=1053.693, p=<.004$. Both tests were passed, allowing for factorial analysis.

All items were included in the scale reduction and factorial analysis based on load factor and the percent of the total variance explained. Peterson (2000) determined the threshold for each as $56.6 \%$ variance explained and an average absolute factor loading above .32 in a meta-analysis of 401 factor analysis studies. The standard of larger than one eigenvalue was used to determine the total variance explained for the survey at $67.3 \%$. The twenty items in the survey had factor loadings ranging from .53 to .88 (see <Table $1>$ ). Therefore, all of the items were suitable for use in the analysis.

The Cronbach's alpha was used to determine internal consistency within the scale items and the entire questionnaire. The whole survey had a Cronbach's alpha of .919. The first scale item, Intention to Use (IU), had a Cronbach's alpha of .722. Perceived Usefulness (PU) had a .859, and Perceived Ease of Use (EoU) had .781. The Cronbach's alpha for scale item four, Subjective Norm (SN), scale item five, Output Quality (OQ), and item six, Result Demonstrability (RD), were .673, .788, and .729 respectively (see <Table $1>$ ). Tavakol and Dennick (2011) reported that the overall Cronbach alpha should be between .700 and .950 . One of the factors is slightly lower than the level, but Tavakol and Dennick (2011) stated that a low number of questions could be the reason.

\subsection{Statistical Test}

A standard multiple regression was performed to determine how different elements in the TAM for online writing homework predicted usage behavior within the theoretical model. According to the model, PU consisted of four possible parts: EoU, SN, OQ, and RD. The item to total correlations was statistically significant to PU at the $p<.004$ level. All of the correlations with PU had a large significant effect size of over .50 (See <Table $2>$ ). The interitem relationships were all also significant, with only one being slightly below the medium effect size for the Pearson's correlation as defined by Cohen (Prajapati et al., 2010). The inter-item and item to total correlations indicate a proper sample size for statistical testing (Amjad et al., 2020).

The overall regression utilizing the four predictors was statistically significant at an adjusted $R^{2}=.59, F(4,85)$

〈Table 2〉 Results of Standard Multiple Regression to Predict PU from EoU, SN, OQ, and RD

\begin{tabular}{l|c|c|c|c|c|c} 
& PU & EoU & SN & OQ & RD & $\beta$ \\
Perceived Ease of Use (EoU) & $.629 * *$ & & & & $.24 *$ \\
\hline Subjective Norm (SN) & $.562 * *$ & $.462 * *$ & & & .07 \\
\hline Output Quality (OQ) & $.659^{* *}$ & $.473 * *$ & $.713 * *$ & & $.43 * *$ \\
\hline Results Demonstrability (RD) & $.531^{* *}$ & $.602 * *$ & $.304 * *$ & $.266^{*}$ & $.25 *$ \\
\hline$* p<.05, * * p<.004$
\end{tabular}


$=32.83, p \leq .004$, indicating that the model can explain $59 \%$ of the variance of the regression. Three of the four predictors were statistically significant, with a positive slope indicating that the perceived usefulness also increased as the predictor increased. EoU had a standardized coefficient $\beta=.24, t(89)=2.60, p=.011$, OQ had a standardized coefficient $\beta=.43, t(89)=4.30, p \leq .004$, and RD had a standardized coefficient $\beta=.25, t(89)=$ 2.93, $p=.004$. SN did not statistically affect the perceived usefulness (See $<$ Table $2>$ ).

The second stage of the model looks at how the predictors $\mathrm{PU}, \mathrm{EoU}$, and $\mathrm{SN}$ affect the students' Intention to Use (IU). The item to total (range of .65 to .83) and inter-item correlations (between .46 and .63) were both in the range that made the test valid with medium to large effect sizes. This section of the model had an adjusted $R^{2}=.74, F(3,87)=86.88, p \leq .004$, indicating that the model can explain $74 \%$ of the variance of the regression. All three predictors for IU were statistically significant. PU had the highest standardized coefficient $\beta=.58, t(90)=7.66, p \leq .004$, EoU had a standardized coefficient $\beta=.18, t(90)=2.61, p=.011$, and $\mathrm{SN}$ was at $\beta=.24, t(90)=3.57, p \leq .004$. Since all beta coefficients were positive, IU increases as PU, EoU, and SN increase (see $<$ Table $3>$ ).

The final standardized regression was run to determine how IU affected a students' Usage Behavior (UB). This section of the model had an adjusted $R^{2}=.05, F(1$, $94)=6.32, p=.014$, indicating that only $5 \%$ of the variance of the regression can be explained by the model. The standardized coefficient $\beta=.25, t(95)=2.51, p=.014$.

\section{Discussion}

Based on these results, as a student's intention to use (IU) increases, the usage behavior (UB) also increases. [Figure 2] illustrates the relationships discovered in the survey using the TAM to help explain students' attitudes towards using an online system for writing homework.

〈Table 3〉 Results of Standard Multiple Regression to Predict IU from PU, EoU, and SN

\begin{tabular}{|c|c|c|c|c|c|}
\hline & IU & PU & EoU & SN & $\beta$ \\
\hline Perceived Usefulness (PU) & $.826 * *$ & & & & $.58 * *$ \\
\hline Perceived Ease of Use (EoU) & $.653 * *$ & $.627 * *$ & & & $.18^{*}$ \\
\hline Subjective Norm (SN) & $.650 * *$ & $.571 * *$ & $.461 * *$ & & $.24 * *$ \\
\hline
\end{tabular}

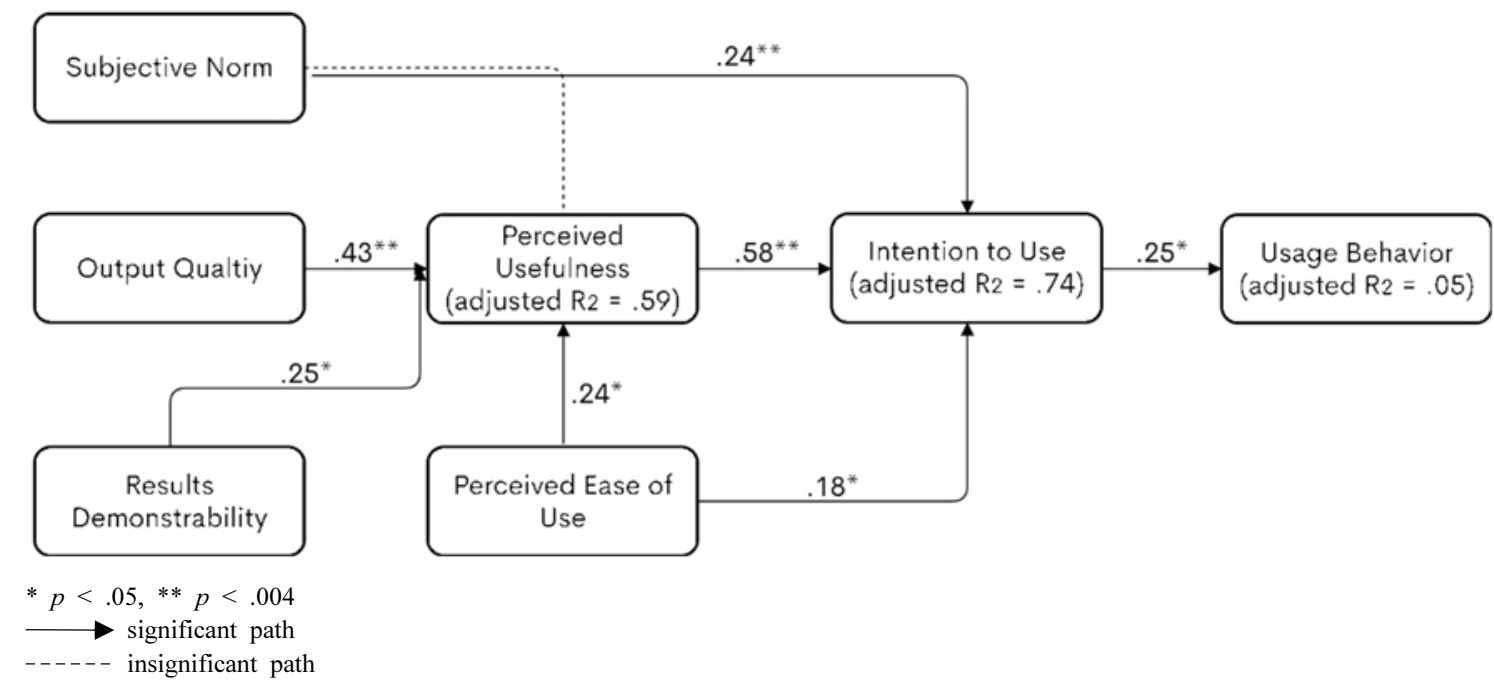

[Figure 2] Results of the structural model for student attitudes towards online writing systems 
Students perceived usefulness as being affected by the quality of the output, results demonstrability, and ease of use. The effects of the variables were all positive as related to the perceived usefulness. This result indicates that as the $\mathrm{OQ}, \mathrm{RD}$, and EoU increased, the perceived usefulness also increased. The subjective norm or the social aspects of the system were not viewed as being statistically significant to usefulness.

The output quality (OQ) was found to be positively statistically significant. As OQ increased, perceived usefulness (PU) grew, which led to a higher IU and usage behavior for the students. The results for OQ ranged from 3.22 to 3.01 , which fell between the responses of strongly agree and agree, indicating the importance of providing meaningful feedback to students that would help them achieve the goals of the course. The OQ in this study focused on teacher-provided feedback to students to help students improve their writing skills. Teacher feedback consisted of rubrics or checklists tailored to the goals of each assignment, as well as individualized comments to highlight the strengths and weaknesses of the student's writing. Survey results showed that students believed the quality of feedback they received was high and possibly better than what they would have received in an offline class setting.

Results demonstrability (RD) was also found to be positively statistically significant. As RD increased, the students' perceived usefulness (PU) increased. RD questioned whether students felt they understood the VLE for completing writing homework well enough to communicate how it was used to others. Confidence in completing this task revealed that students had obtained a good working knowledge of the system and were comfortable using it. The results for $\mathrm{RD}$ fell between the range of 3.23 and 3.12, reflecting student perceptions they had developed a clear understanding of how to navigate and utilize the interface of a VLE for completing writing homework by the end of the semester.

Subjective norm (SN) was not shown to influence students' perceived usefulness (PU) significantly. It has been established that PU plays an essential role in students' usage behavior, and $\mathrm{OQ}, \mathrm{RD}$, and EoU contribute to students' PU of using a VLE for writing homework. Therefore, it is curious that SN did not also contribute to students' PU. SN focuses on the social aspects of influencing student use of VLEs. It may be inferred that SN did not influence PU as strongly because students were required to utilize a VLE to participate in the class and complete their homework assignments due to the circumstances of the COVID-19 pandemic. In this case, PU may not have been considered as strongly since the use of VLEs was simply perceived as a mandatory, pragmatic approach to the unique conditions precipitated by the COVID-19 pandemic.

Student's perceived ease of use (EoU) was positively linked to perceived usefulness (PU) and intention to use (IU), ultimately increasing usage behavior. The results of EoU ranged from 3.46 to 3.04, showing that students were comfortable with the user-friendliness of online platforms and their ability to navigate the system. These high EoU numbers reinforce the belief that students have developed a clear working knowledge of using online systems for submitting homework, as demonstrated through RD. EoU, along with RD, may indicate student willingness to adapt to new technologies in the $4^{\text {th }}$ industrial revolution. As Hashim and Yunus (2019) and Alakrash \& Razak (2020) discussed, utilizing technology in the classroom helps teach practical skills in a range of subjects. Students understand that they must be willing to adapt and familiarize themselves with advances in technology to maintain pace in a competitive learning setting.

Second, the student attitudes related to the intention to use the system were significantly affected by PU, EoU, and $\mathrm{SN}$. The perceived usefulness, $\beta=.58$, was more than three times more important to the intention to use than the ease of use at a $\beta=.18$, but only slightly more than twice that of the $\mathrm{SN}$ at $\beta=.24$. All of the factors were positively related, indicating that as PU, EoU, and $\mathrm{SN}$ increased for a student, the intention to use increased. 
Interestingly, subjective norm (SN) had a significant positive impact on the students' intention to use (IU) online systems for completing writing homework. This result would ultimately contribute to increasing students' usage behavior. As Park (2009) mentions, SN plays a crucial social role in influencing students' attitudes towards e-learning systems. Park also discusses the pressure in Korea for students to keep up with technological advances in a competitive university environment. With this in mind, and the added effects of the COVID-19 pandemic, students may have felt the need to utilize VLEs to keep up with their peers, influencing their IU.

\section{Conclusion and Suggestions}

The students who were better able to understand the system to the extent that they felt they could explain it to someone else (RD) had a higher perception of the system's usefulness. Therefore, teachers should make sure that students are clear on the use of the system and be prepared to help students understand it. Some teachers might need additional training in the use of the system to inform the students in the best manner. Because the perceived usefulness of VLEs for writing was positively affected by the quality of the output, teachers should remember that the feedback needs to be as thorough as possible. Teachers should do their best to work with students to help them understand how to use the VLE to help improve the students' perceptions of usefulness. The results of SN suggest that students may have been satisfied with using an online platform for writing homework; however, their satisfaction may be limited since utilizing VLEs was the only option available.

The study has some limitations that must be considered. A limitation was that the study utilized participants from one university in South Korea; other responses might happen in a different educational setting. The study was held during the COVID pandemic in Korea. Both the semesters when data were collected had to meet online due to government restrictions. Because the entire course was administered in the VLE, some social aspects of meeting in person were lost in moving the classroom online. The English teachers in this study were both native speakers who had to explain how to use the VLE to non-native speakers. This added another layer of difficulty to the administration of the class. While it increased the English being used to explain $4^{\text {th }}$ industrial revolution issues, it could have caused some language-related challenges that could have been avoided. Finally, there were some possible technical limitations within the study. The students had to use their equipment to complete the assignments and did not have access to school computers as they would have had if they were on campus.

For further research, it would be interesting to see if the same results could be reached with a different set of students from diverse backgrounds. Next, further research into the outcomes for students enrolled in a class not under COVID-19 restrictions would be helpful. By comparing this study with a post-coronavirus study, the social aspects predicted in the model as affecting perceived usefulness could be better understood. Also, it would be interesting to see what elements most affected students in terms of output quality or teacher feedback.

Using a VLE to teach in the EFL setting is a viable option in all types of EFL writing classrooms, whether exclusively online or in a blended format with offline classes. To best aid students in accomplishing the goals of the class, teachers need to help them reach a level of system knowledge, provide complete feedback and emphasize the social need to utilize the system. When these three aspects are reached, students tend to have a higher attitude towards using the VLE to improve their English writing skills. The students also gain $4^{\text {th }}$ industrial revolution skills through interacting and using the system, which should be transferable to future workplace applications.

The restrictions posed by the COVID-19 pandemic, which precipitated the shift from offline to online learning, allowed this study to explore and better understand how technology can be used to improve education in the EFL 
classroom. Given the results of this study, students' attitudes toward utilizing VLEs are positive and therefore VLEs hold the potential to be utilized effectively. Whether VLEs can or should completely replace the physical classroom remains up to debate, but this study does illustrate how the use of VLEs can act as a viable resource to assist teachers in achieving their goal of educating students.

\section{References}

Alakrash, H. M., \& Razak, N. A.(2020). "Redesigning the English Classroom Towards Fourth Industrial Revolution, Are the Students Motivated", The Asian ESP Journal 16(4), 6-21.

Amjad, M., Hussain, R., \& Siddiq, S.(2020). "Pakistani ESL Learners on the Internet: Explorations into Factors Influencing their Online Language Learning Behaviour", Global Language Review V(III), 151-162. https://doi.org/10.31703/glr.2020 (V-III). 16

Anatolyevna, V., Butt, S., Salmani, H., \& Zaheer, S.(2018). "Do Mobile Technology in the Classroom Really Improve Learning Outcomes?", International Journal of Evaluation and Research in Education (IJERE) 7(3), 188-193.

Beavers, A. S., Lounsbury, J. W., Richards, J. K., Huck, S. W., Skolits, G. J., \& Esquivel, S. L.(2013). "Practical considerations for using exploratory factor analysis in educational research", Practical Assessment, Research \& Evaluation 18(6), 1-13.

Boonmoh, A., Jumpakate, T., \& Karpklon, S.(2021). "Teachers' Perceptions and Experience in Using Technology for the Classroom", Computer-Assisted Language Learning Electronic Journal 22(1), 1-24.

Cai, W., Ivory, D., Smith, M., \& Lemonides, A.(2020, July 29). "More Than 6,600 Coronavirus Cases Have Been Linked to U.S. Colleges", New York Times, Retrieved from http://www.nytimes.com

Davis, F. D.(1986). “A technology acceptance model for empirically testing new end-user information systems: Theory and results", Doctoral dissertation, Cambridge, MA: MIT Sloan School of Management.

Davis, F. D.(1989). "Perceived usefulness, perceived ease of use, and user acceptance of information technology", MIS Quarterly 13, 319-339.

Davis, F. D., Bagozzi, R. P., \& Warshaw, P. R.(1989). "User acceptance of computer technology: A comparison of two theoretical models", Management Sci. 35(8), 982-1003.

Davison, C., \& Lazaros, E.(2015). "Adopting Mobile Technology in the Higher Education Classroom", The Journal of Technology Studies 41(1), 30-39.
Dziuban, C. D., \& Shirkey, E. C.(1974). "When is a correlation matrix appropriate for factor analysis? Some decision rules", Psychological Bulletin 81(6), 358-361.

Graham, C. R.(2006). "Blended learning systems: Definition, current trends and future directions", In C. J. Bonk, \& C. R. Graham (Eds.), The handbook of blended learning. Global perspectives, local designs (pp. 3-21), Pfeiffer.

Griffin, J., \& Minter, D.(2013). "The Rise of the Online Writing Classroom: Reflecting on the Material Conditions of College Composition Teaching", College Composition and Communication 65(1), 140-161.

Hashim, H. U., \& Yunus, M. M.(2019). "Digital Learning with Massive Open Online Courses (Moocs): English for Communication", Modern Journal of Language Teaching Methods 9(3), 1-5.

Jones, S., Richards, A., Cho, Y., \& Lee, Y. J.(2019). "Pedagogical Ramifications of Fourth Industrial Revolution Technology on General English Classes from Korean Students Perspective", Korean Journal of General Education 13(4), 501-532.

Kit, L. W., \& Ganapathy, M.(2019). "The Reality of Malaysian ESL Teachers' ICT Pedagogical Practices: Challenges and Suggestions", English Linguistics Research 8(3), 39-48.

Nelson, A.(2013). "Design of the Technology-Rich Classroom Practices and Facilities Environments", Educational Technology 53(6), 3-12.

Ni, A.(2013). "Comparing the Effectiveness of Classroom and Online Learning: Teaching Research Methods", Journal of Public Affairs Education 19(2), 199-215.

O'Connor, K.(2020). "Creating, Curating and Supporting the Wall-Less Classroom", International Journal for e-Learning Security (IJeLS) 9(1), 604-609.

Ock, H.(2020, April 22). "S. Korea Struggles with Unprecedented Online Learning", Korea Herald, Retrieved from http://www. koreaherald.com

Park, S. Y.(2009). "An Analysis of the Technology Acceptance Model in Understanding University Students' Behavioral Intention to Use e-Learning", Journal of Educational Technology \& Society 12(3), 150-162.

Peterson, R. A.(2000). "A meta-analysis of variance accounted for and factor loadings in exploratory factor analysis", Marketing Letters 11(3), 261-275.

Prajapati, B., Dunne, M., \& Armstrong, R.(2010). "Sample size estimation and statistical power analyses", Optometry Today 16(7), 10-18

Raja, R., \& Nagasubramani, P. C.(2018). "Impact of modern technology in education", Journal of Applied and Advanced Research 3(1), 33-35.

Shepherd, R.(2018). "Digital Writing, Multimodality, and Learning Transfer: Crafting Connections between Composition and Online Composing", Computers and Composition 48, 103-114.

Surani, D., \& Hamidah, H.(2019). "Students Perceptions in Online 
Class Learning During the Covid-19 Pandemic", IJoASER (International Journal on Advanced Science, Education, and Religion) 3(3), 83-95.

Tavakol, M., \& Dennick, R.(2011). "Making sense of Cronbach's alpha", International Journal of Medical Education 2, 53-55.

Townsend, J., Nail, A., Cheveallier, J., \& Browning, A.(2013). “An Online Writing Partnership: Transforming Classroom
Writing Instruction”, The English Journal 102(4), 74-81.

Venkatesh, V., \& Davis, F. D.(2000). "A theoretical extension of the technology acceptance model: Four longitudinal field studies", Management Science 46(2), 186-204.

Wen, K. Y. K., \& Kim Hua, T.(2020). "ESL Teachers' Intention in Adopting Online Educational Technologies during COVID-19 Pandemic", Journal of Education and E-Learning Research 7(4), 387-394. 


\section{기술 수용 모델을 이용하여 EFL 작문을 위한 가상 학습 환경에 대한 태도 이해}

찰스 코퍼랜드 ${ }^{1}$, 존 프랜지스2

1단국 대학교 자유교양대학 외국어교육전담조교수

2단국 대학교 자유교양대학 강의전담조교수

초록

본 정량적 사례 연구는 기술 수용 모델(TAM)을 이용하여 가상 학습 환경(Virtual learning environment: VLE) 사용에 대한 $\mathrm{EFL}$ 학습자의 태도를 이해하고자 했다. 본 연구에서는 필수 $\mathrm{EFL}$ 작문 과정에 등록한 97 명의 대학생을 대상으로 설문조사 를 실시하였다. 데이터가 TAM에 적합하도록 요인 감소를 적용했고, 데이터 분석을 위해 표준 다중 회귀 분석을 사용하였다. 연구 결과는 학습자의 인지된 이용 용이성, 결과 품질, 결과 입증 가능성, 주관적 규범, 인지된 유용성, 이용 의사가 긍정적일수록 학습자가 VLE를 사용하고 받아들일 가능성이 더 높다는 것을 보여주었다. VLE 사용은 학습자가 언어 수준을 향상시키고 4 차 산업혁명 기술을 구축하는 데 도움이 될 것이다. 향후 교수자는 EFL 작문 수업을 위해 VLE사용을 고려할 필요가 있음을 본 연구는 제언하고 있다.

주제어: 기술 수용 모델(TAM), 가상 학습 환경(VLE), EFL 쓰기, 4차 산업 혁명, 학습자 태도 